\title{
5. Advertising and the Apparatus: Cinema, Television, and Out-of-Home Screens
}

\author{
Yvonne Zimmermann
}

\begin{abstract}
In this chapter, the notion of the dispositif serves as a conceptual framework to both theorize and analyse the programming of moving image advertising on three types of screens: cinema, network-era television, and digital out-of-home displays. The chapter shows how screen ads stitch together different forms of intermittent movements - of bodies, images, and objects - and thus help create flows. In bringing the programme in conversation with the dispositif, the chapter also draws attention to the programme, which in cinema studies, if not to the same extent also in media studies, is an extremely under-researched category despite its importance for production as well as for reception. Any study interested in the pragmatics of screen advertising as well as screen media cannot do without the programme.
\end{abstract}

Keywords: dispositif, programme, out-of-home advertising, cinema, television, movement and mobilities

Recent research into non-theatrical film and screen advertising has put an emphasis on the topologies of moving pictures and has started to explore the many sites and networks of moving images beyond commercial cinema circuits. Behind this approach is the idea that sites are key to understanding how moving images were and are put to use. Sites matter for the many particular ways moving images are exhibited and experienced. Moving images, in other words, have been comprehended

Florin, B., P. Vonderau, Y. Zimmermann, Advertising and the Transformation of Screen Cultures. Amsterdam: Amsterdam University Press, 2021 DOI 10.5117/9789462989153_CHO5 
and studied as being site-specific, as sited in concrete places, practices, and materials. ${ }^{1}$

In what follows, I do not wish to further explore screen advertising as a site-specific phenomenon. Instead, I propose an approach that focusses on different media dispositifs in which screen advertising has been involved. Following Jean-Louis Baudry, the notion of dispositif describes a particular set of media technologies and specific conditions of reception. The three historically and geographically distinctive dispositifs I will examine are post-war cinema in Western Europe, home television in the network era in the United States with an eye to public service broadcasting in Western Europe, and contemporary train platforms in Germany equipped with digital out-of-home screens. The reason for selecting these dispositifs resides in their respective prevalence at a certain time and place: cinema and broadcast television were the dominant forms of mass media in the 2oth century, while, with the advent of digital signage and out-of-home screens, out-of-home media dispositifs have acquired more importance and visibility. The three dispositifs, at specific moments in time, constitute and have constituted the predominant viewing modes of moving images - and hence also the principal viewing modes of screen advertising, for, as mentioned above, advertising has been an integral part of these dispositifs.

Dispositifs are first of all specific spatial arrangements that produce a viewing position in particular ways. Baudry's notion of dispositif and his description of 'the positioned viewer' may create an impression of fixation and transhistorical stability both of the dispositif as a whole and of the viewer position. However, the elements of dispositifs are subject to historical change; dispositifs are historically relative and hence historically specific. Consequently, to echo Jacques Aumont, 'the study of the dispositif is inevitably a historical study: there is no dispositif outside history'. ${ }^{2}$

The viewer position within a particular dispositif is also not stable. Instead, in all dispositifs under discussion here, there is a constant, ongoing effort to sustain and direct audience engagement, and thus a continuing process of positioning viewers. The procedural element of the positioning process

1 See, for example, Gregory A. Waller, 'International Harvester, Business Screen and the History of Advertising Film', in Films That Sell: Moving Pictures and Advertising, ed. Bo Florin, Nico de Klerk, and Patrick Vonderau (London and New York: Palgrave, 2016), 40; and Patrick Vonderau, 'Introduction: On Advertising's Relation to Moving Images', in Films That Sell, ed. Florin, de Klerk, and Vonderau, 13.

2 Jacques Aumont, L'Image (Paris: Nathan, 1990), 147. 
points to the temporal dimension of time-based media dispositifs. Or, as Bernard Vouilloux has highlighted, the dispositif is not an arrangement for simply imposing behaviours; rather, it regulates the movement of forces that traverse it.

The dispositive captures and channels energy in order to redistribute it. The dispositive does not have the purity of structures; its form is never anything but the temporally and spatially determined disposition within which are stabilized the flows with which it deals. ${ }^{3}$

Nevertheless, many studies have stressed the spatial element of dispositifs, since dispositifs are usually conceived as spatial arrangements of spectator, representation, and machinery. My attempt here is to examine screen advertising's place in the temporal structure of the three dispositifs to learn more about screen advertising's part in the process of positioning viewers. To this end, I explore screen advertising as an element in the time structure and chronological sequencing of movement within the above-mentioned dispositifs. Thereby, three types of movement are considered: moving images on the screen, bodily movements of the viewers, and movements of objects. While the first type of movement draws attention to the relations between moving images and directs the focus on the programme structure of moving images and screen advertising's place in it, the second two types highlight the relations of moving images to other forms of movement occurring in the respective dispositifs.

From this description, it should be clear that the notion of dispositif that underlines this essay does not borrow Baudry's narrow focus on the cinematic dispositif (even though this will be important when looking at the cinema dispositif), but constitutes a broadened understanding of the dispositif as the configuration or arrangement of heterogeneous elements, or, as Michel Foucault has put it, the 'connection that exists between these heterogeneous elements.' ${ }^{4}$ The notion of dispositif has been re-conceptualized in media studies, as well as in other scientific fields, if we think of the work

3 Bernard Vouilloux, 'Du dispositif', in Discours, image, dispositif, ed. Philippe Ortel (Paris: L'Harmattan, 2008), 20, quoted in Will Straw, 'Pulling Apart the Apparatus', Recherches sémiotiques 31, no. 1-2-3 (2011): 66. https://www.erudit.org/fr/revues/rssi/2011-v31-n1-2-3-rssio1601/1027441ar/ (last accessed 6 April 2021).

4 Michel Foucault, Power/Knowledge: Selected Interviews and Other Writings 1972-1977, ed. Colin Gordon (New York: Pantheon Books, 1980), 194-195. Note that, in English, the term dispositif in Foucault's work has been translated as apparatus. To avoid any confusion, I use the French term dispositif throughout the essay. 
by Foucault, Gilles Deleuze and Félix Guattari, and Michel de Certeau, among many others. For the present purpose, the concept of dispositif is understood, as outlined by Frank Kessler, as a heuristic tool 'offering ways to account for the complexities of media(texts) in situational contexts offering, or aiming at producing specific spectatorial positions.' ${ }^{5}$ This approach is in line with Maria Tortajada and François Albera's take on the dispositif as an epistemic schema and in support of their idea that the dispositif needs to be constructed as a notion. ${ }^{6}$ Following Foucault, I am also interested in how the interplay of various elements - screen advertising being one of them - produces power structures. Because of the relative openness of the concept, it can be applied to various levels of analysis, which will be the case in the following.

Therefore, instead of studying screen advertising in isolation, I wish to study it in relation to other moving images as well as in relation to moving bodies and moving objects in order to better understand how screen advertising structures time and contributes to producing specific viewing positions. I argue that - despite major differences between the three examined dispositifs in terms of historical context, institutional anchoring, geographical location, and media - screen advertising occupies a somewhat identical place in between time sequences and that it plays an equal role in structuring movements in time: it manages transitions and structures flows. As such, screen advertising is a key actor in the positioning processes within different media dispositifs.

While this essay is informed by concepts developed in cinema and television studies (most notably Raymond Williams's notion of flow) as well as in media studies, it also draws on paradigms from the social sciences. It is particularly inspired by movement and mobilities studies and by Mimi Sheller and John Urry's endeavour to 'offer new perspectives on making of place through the temporal coordination of mobilities'. ${ }^{7}$ For the present purpose, Sheller and Urry's attempt may translate into an effort to study the making of dispositifs through screen advertising's temporal coordination of movements and mobilities.

5 Frank Kessler, 'Notes on dispositif', work in progress paper, version from November 2007, pp. 1-19, here p. 17, http://www.frankkessler.nl/wp-content/uploads/2010/05/Dispositif-Notes. pdf (last accessed 6 April 2021).

6 François Albera and Maria Tortajada, 'The Dispositive Does Not Exist!', in Cine-Dispositives: Essays in Epistemology Across Media, ed. François Albera and Maria Tortajada (Amsterdam: Amsterdam University Press, 2015), 32.

7 Mimi Sheller and John Urry, eds., Mobile Technologies of the City (London and New York: Routledge, 2006), 4. 


\section{Screen Advertising and the Dispositif of Cinema}

Unlike in the United States, where the history of screen advertising has been one of negotiating for a permanent place in commercial cinemas and has been marked by moving in and out of cinemas, ${ }^{8}$ in most Western European countries, screen advertising has been part of regular cinema programmes since the introduction of the long feature film during World War I, if not earlier. In their sales ads, French production companies such as Pathé Frères, Gaumont, Eclipse, and Raleigh \& Robert offered 'views' of work and industrial processes under the label of scènes d'art et d'industrie for the international market in the early 1900s. These process films circulated in the short film programmes of commercial cinemas worldwide. Even though written sources on the production of these films are mostly missing, it can be assumed that these films were sponsored by companies with the aim to explain, brand, and promote their products - among them, mainly food and consumer goods such as cigars, tea, cookies, and milk powder. Tourist associations also sponsored travelogues from early on to promote sights and instigate travel. In Germany, advertising film pioneer Julius Pinschewer had built a theatrical distribution network for short advertising films by 1912 . On the basis of this network, commercials became a regular part of the programme of shorts in cinemas in Germany. ${ }^{9}$ This model was copied after the war in many other European countries, among them Switzerland, where Praesens Film and its spin-off Central Film had a quasi-monopolistic position in theatrical distribution of advertising films starting in the mid $1920{ }^{10}{ }^{10}$ With the shift during World War I from the short film programme towards a (usually fictional) feature film as the standard programme format of commercial cinema entertainment, the rest of the short film programme shrank into

8 See Deron Overpeck, 'Subversion, Desperation, and Captivity: Pre-film Advertising in American Film Exhibition Since 1977', Film History 22, no. 2 (2010): 219-234; Yvonne Zimmermann, 'Advertising and Film: A Topological Approach', in Films That Sell, ed. Florin, de Klerk, and Vonderau, 21-39, esp. 26-30.

9 On Pinschewer, see Martin Loiperdinger, 'Julius Pinschewer - Pionier, Klassiker und Avantgardist des Werbefilms', in Julius Pinschewer. Klassiker des Werbefilms, DVD Booklet (Berlin: absolut Medien, 2010), 3-12; André Amsler, 'Wer dem Werbefilm verfällt, ist verloren für die Welt': Das Werk von Julius Pinschewer 1883-1961 (Zurich: Chronos, 1997). For a broader history of advertising film in Germany, see Ralf Forster, Ufa und Nordmark: Zwei Firmengeschichten und der deutsche Werbefilm 1919-1945 (Trier: Wissenschaftlicher Verlag Trier, 2005).

10 See Regula Bochsler and Pascal Derungs, eds., Und führe uns in Versuchung: 1oo Jahre Schweizer Werbefilm (Zurich: Museum für Gestaltung, 1998). 
what would be called the programme of shorts. ${ }^{11}$ This programme of shorts usually started with a section of commercials (one to six per programme, depending on the country), ${ }^{12}$ followed by a series of trailers, newsreels, and a so-called Kulturfilm (a cultural film, described in greater detail below). In some countries, commercials were not part of the programme of shorts, but were screened in the intermission. In the late 1940s, such was the case in Belgium, France, some Scandinavian countries, and some theatres in Italy, whereas in England, the Netherlands, Switzerland, and in other theatres in Italy, commercials were part of the programme of shorts. ${ }^{13}$ Contrary to what one of the few historical sources for this very vague survey states, commercials were shown at the beginning of screenings in Sweden in the 1940s. ${ }^{14}$ Kulturfilm were generally non-fictional films of 10 to 20 minutes that, in a more or less entertaining way, imparted knowledge on educational topics such as geography, biology, history, and customs. ${ }^{15}$ While commercials and trailers were blunt advertisements, the Kulturfilm, albeit normally sponsored by public and private organizations, was not permitted to openly promote goods and services, but had to display their qualities in a discreet way. Otherwise, they would not have been awarded the Kulturfilm label. This label was vital for the films to make it into the regular programmes of cinemas. Starting in 1926, cinema owners in Germany received tax breaks as an incentive to include Kulturfilm in their programmes. This helped establish this category of indirect screen advertising in Germany, as well as in Austria and Switzerland (and other countries at certain points in time). The ideology behind this policy was to domesticate potentially 'detrimental' cinema entertainment by counterbalancing it with bourgeois education. ${ }^{16}$

11 The interwar period saw a variety of programme formats in European cinemas that this short overview cannot consider. Double features and continuous programming were common in Great Britain, for example. Some cinemas specialized in actualities, in other words, newsreels. 12 See, for example, Schweizerischer Reklame Verband, ed., Die Grundlagen der Filmwerbung: Eine Wegleitung für Auftraggeber (Zurich, [1949]).

13 See ibid., for example.

14 Carina Sjöholm, Gå på bio. Rum för drömmar ifolkhemmets Sverige (Stockholm and Stehag: Brutus Östlings Bokförlag Symposion, 2003), 181. A transnational comparison of programme formats and the placement of commercials in cinemas is a research desideratum.

15 See Yvonne Zimmermann, 'Advertising and Film: A Topological Approach', in Films That Sell, ed. Florin, de Klerk, and Vonderau.

16 See Klaus Kreimeier, Antje Ehmann, and Jeanpaul Goergen, eds., Geschichte des dokumentarischen Films in Deutschland, vol. 2: Weimarer Republik 1918-1933 (Stuttgart: Reclam, 2005); Peter Zimmermann and Kay Hofmann, eds., Geschichte des dokumentarischen Films in Deutschland, vol. 3: 'Drittes Reich'1933-1945 (Stuttgart: Reclam, 2005); Ramón Reichert, ed., Kulturfilm im 'Dritten Reich' (Vienna: Synema, 2006); Yvonne Zimmermann, ed., Schaufenster Schweiz: Dokumentarische Gebrauchsfilme 1896-1964 (Zurich: Limmat, 2011). 
Since screen advertising's place in the programme is central to examining its relation to other types of moving images as well as to other types of movement, it may be useful to think about the programme in more detail. The term 'programme' is ambiguous; it can mean the announcement of the course of action of a presentation (e.g., the bill of fare or a TV guide), or it can designate the predefined succession and the procedure of a presentation, an operating process, or a technical installation. Finally, programme can also describe the determination of intentions and goals and a wilful intent (e.g., party platform). ${ }^{17}$ In regard to mass media, the term has a double structure, with programme meaning both the announcement of a (film, radio, or TV) programme and the actual screening or broadcasting of what is (or is not) announced. ${ }^{18}$ In the following, I am interested in the second meaning of the word. Programme in this sense can be defined as the relation between many, usually diverse, products, which are presented in a sequence over time and in a single place or channel. ${ }^{19}$ Programmes organize media objects in time, they are principles of temporal arrangements, they set the pace and rhythms, and they structure sequences and flows. In doing so, programmes not only organize the presentation of moving images, they also organize the reception of moving images and as such are central for media experience. ${ }^{20}$ Thus, programmes always have two sides; they are at the same time a category of production and presentation (for those who organize and screen or broadcast programmes) and a category of reception (for those who experience them).

In his studies on the ideological effects of film and the dispositif, Baudry does not pay any attention to the discursive organization of moving images and the programme. ${ }^{21}$ Instead, Baudry is interested in how filmic instruments produce specific ideological effects (through 'the impression of reality') beyond the 'messages' of single films or the arrangement of films, in other words, programmes. And he underlines how the spatial and technical arrangement of cinema, its dispositif, produces ideological effects,

17 Ludwig Fischer, 'Vorwort', in Programm und Programmatik: Kultur- und medienwissenschaftliche Analysen, ed. Ludwig Fischer (Konstanz: UVK, 2005), 11.

18 See Knut Hickethier, 'Aspekte der Programmemtheorie des Fernsehens', Communications, no. 3 (1991): 329-330.

19 Knut Hickethier, Film- und Fernsehanalyse, $3^{\text {rd }}$ revised ed. (Stuttgart and Weimar: Metzler, 2001), 216.

20 Ludwig Fischer, 'Vorwort', in Programm und Programmatik: Kultur- und medienwissenschaftliche Analysen, ed. Ludwig Fischer (Konstanz: UVK, 2005), 13.

21 Jean-Louis Baudry, 'Effets idéologiques produits par l'appareil de base', Cinéthique no. 6/7 (1970); Jean-Louis Baudry, 'Le dispositive. Approches métapsychologiques de l'impression de réalité', Communications 23 (1975): 56-72. 
most notably through the subject positioning of spectators. While Baudry stresses the role of the spatial arrangement of technology, moving images, and bodies in organizing perception and creating ideological effects, he fails to perceive that cinema is more than the screening of a single film to positioned spectators. Baudry's notion of the dispositif of cinema implies arrest and does not account for the complex dynamics of movements of images and bodies that produce the space of cinema. It reduces cinema to the moment when audiences are sitting immobilized in the dark, positioned by the projector behind them and the screen in front of them. However, the moments when audiences are fixed and captivated by the screen are transitory. Audiences enter the cinema, settle into their seats, may get up at the intermission, and may leave the auditorium to purchase food and drinks in the foyer or visit the bathroom; they take a seat again, get up (again), and leave the cinema after the screening. The degree of attention paid to the screen also varies and can shift between inattention and captivation. The cinema also is not a darkened room, but it is characterized by changing intensities of light and the alternation between light and darkness.

Thus, the dispositif of cinema consists of a complex dynamic of light and darkness and of overlapping and interacting movements of bodies in the auditorium and of images on the screen. Within this dynamic, commercials can be found in the transitional phase when attention shifts away from the social interaction in the auditorium towards the screen and the audience turns into individual spectators. When screened at the beginning of the programme of shorts, commercials orchestrate this transition on several levels. They are at the threshold between still and moving images on the screen: they moderate the transition from advertising slides to advertising films, thus setting the images on the screen in motion. While initiating movement on the screen, commercials at the same time help bring bodily movements to a temporary halt. Commercials also mark the moment when the lights in the cinema dim and attention is geared towards the screen. Thus, they moderate the transition from light to darkness, from social interaction to individual concentration, from bodily movement to bodily arrest, from still images to moving images, and from potential inattention to the screen to potentially growing captivation. If screened in the intermission, commercials again interplay with changing lighting conditions (from darkness to lights turned on, and from light to darkness again) and orchestrate the potential movement of bodies during the intermission. In this way, commercials temporally organize the movements of bodies in the cinema. Importantly, commercials also moderate the interruption of the feature movie during the intermission by keeping the movement of images on the screen going until 
the feature film sets in again. While commercials placed at the beginning of the programme of shorts substitute the movement of arrested bodies, commercials screened in the intermission maintain the movement of images on the screen.

It is not only commercials, but the programme of shorts as a whole with its different types of advertising that is involved in this management of transition: beginning with blunt advertising for goods and services, the visibility of advertising continuously decreases in the course of the programme of shorts, ending with the Kulturfilm, indirect advertising, and product placement. The programme of shorts thus manages a seamless transition towards the main attraction, the feature fiction film and its predominant form of advertising, product placement. ${ }^{22}$ In this sense, screen advertising orchestrates the subject positioning of the spectator that is central to theoreticians of the cinematic apparatus and the dispositif. Screen advertising is at the threshold between the real world and the imaginary. In Baudry's psychoanalytical wording, one could claim that screen advertising puts audiences to sleep and helps spectators fall into a dreamlike state. In this way, screen advertising plays an important role as an accomplice of the dispositif of cinema in positioning - and disciplining - audiences.

\section{Screen Advertising as Discrete Programme Unit and Mini Programme}

Screen advertising points to the necessity to include the programme in the analysis of time-based media dispositifs. Early cinema borrowed the notion of the programme from theatre and vaudeville. From the latter, it also borrowed its programme format (a sequence of short films). Like theatre and vaudeville performances, cinema screenings are discrete events. Each screening is singular and, to a certain extent, a performance event with a participatory character. And, unlike television with its temporal infinity, cinema screenings are limited in time - they have a beginning and an end - and the temporal unfolding of the programme is sequential. Within this framework, programme units are distinct and the transition from one unit to the next is often marked by additional signs such as fully opening the curtains or darkening the auditorium when the feature film

22 On product placement, see Patrick Vonderau, 'Kim Novak and Morgan Stairways: Thinking about the Theory and History of the Tie-in', in Films That Sell, ed. Florin, de Klerk, and Vonderau, 209-220. 
starts. In the case of the programme of shorts, the programme sections of commercials and trailers can be considered mini programmes within the programme of shorts.

This is important for any study of advertising that is interested in exhibition and reception, but also in the production of moving image advertising. In exhibition practice, in the majority of cases, commercials do not come alone and do not stand alone. Instead, they are part of a commercial programme unit. Sequentially organized in small programmes, commercials are perceived by audiences not in isolation as individual advertisements, but in relation to and in interaction with other commercials. This is also evident in the fact that we speak of watching screen advertising (Werbung) rather than of watching advertisements (Werbefilme). Commercials then raise a somewhat similar question as the shorts in early cinema's short film programmes - namely, what is the unit - and, as a consequence, the object of study? Is it the individual film or the programme? The answer of early cinema scholars is unequivocal: it is the programme. As Andrea Haller and Martin Loiperdinger argue, in early cinema, the individual films were not considered important in the overall programme composition. Rather, the impression as a whole was significant: 'The form of the programme was the determining factor, not the content'. ${ }^{23}$ This finding is not immediately transferable to the mini programmes of commercials, since they are part of larger programmes and since their aesthetic and economic programme rationale differs from that of early cinema's short film programmes. Still, I argue, it is productive to conceive of commercials as programme elements instead of individual short films, because this allows for the study of screen advertising as a relational phenomenon: it permits an examination of the relations between individual commercials as well as the relations between the mini programme of commercials and other programme units, and the overall programme structure. Such an approach can take account of the temporal dimension of moving image advertising and its ontological difference from print advertising.

However, to study screen advertising as a programme - as both a serial and sequential phenomenon rather than as individual advertisements - poses serious historiographical difficulties regarding sources that document

23 See, for example, Andrea Haller and Martin Loiperdinger, 'Stimulating the Audience: Early Cinema's Short Film Programme Format 1906 to 1912', in Early Cinema Today: The Art of Programming and Live Performance, ed. Martin Loiperdinger (New Barnet and Herts: John Libbey, 2011), 9 . 
historical programmes or allow for their reconstruction, for these sources are virtually non-existent. Even if, in archival practice, commercials are often treated as part of a series rather than as individual films, they are regarded as belonging to a series of commercials of a particular company, brand, or advertising campaign, but not as part of an advertising programme. Nico de Klerk is certainly correct when claiming that the programme is 'one of the most, if not the most, underrated and under-researched aspects of the history of screen practice'. ${ }^{24}$ This research deficit is the result of not only a lack of scholarly interest but also the poor documentation of programmes. Programmes may indeed be the worst documented objects in screen history - despite the fact that programmes, rather than individual films, have been formative for the experience of time-based media.

\section{The Place and Role of Commercials in Network-Era Television Programming}

The challenge for television historians is the same as for cinema historians: while individual TV shows, news segments, and commercials may have survived, it is hardly possible to reconstruct the embedding of individual broadcasts within larger historical programme structures due to a lack of sources. Unlike cinema studies, however, television studies have long considered the programme a central object of analysis - although, as William Boddy and others have observed, commercials and network and station promos have received little critical attention as a result of that. ${ }^{25} \mathrm{All}$ the more remarkable is British scholar Raymond Williams's concept of flow, in which a pivotal role is attributed to advertising. Williams argues that flow is the characteristic organization, and hence the characteristic experience of broadcasting systems. For Williams, flow is the defining feature of television both as a technology and as a cultural form, and it is above all advertising that creates the flow. ${ }^{26}$

Writing in 1974, Williams noticed a significant shift from the concept of sequence as programming (with discrete units following one another) to the concept of sequence as flow, that is

24 Nico de Klerk, 'The Moment of Screening: What Non-Fiction Films Can Do', in Triumph der Bilder: Kultur- und Dokumentarfilme vor 1945 im internationalen Vergleich, ed. Peter Zimmermann and Kay Hoffmann (Konstanz: UVK, 2003), 291.

25 William Boddy, 'Advertising Form, Technological Change and Screen Practices in the USA', in Films That Sell, ed. Florin, de Klerk, and Vonderau, 164.

26 Raymond Williams, Television: Technology and Cultural Form (London and New York: Routledge, 2003 [1974]). 
the replacement of a programme series of timed sequential units by a flow of series of differently related units in which the timing, though real, is undeclared, and in which the real internal organisation is something other than the declared organisation. ${ }^{27}$

Focussing on television in the United States and in the United Kingdom, Williams refers to national differences in the organization of broadcasting systems (both radio and television) and the dissimilar role of advertising in it. While advertising has been the main source by which radio and television in the United States are financed, in the United Kingdom, advertising became a feature of television only in the 1950 s and of radio in the early 1970s. ${ }^{28}$ I will come back to different business models, because they are crucial for an understanding of the particular places and roles of advertising in television programmes. The period in television broadcasting Williams refers to is known as the network era in us television history. During this period, from $195^{2}$ to the mid 1980s, three large television networks, $\mathrm{ABC}, \mathrm{CBS}$, and NBC, controlled the us television market. These networks were first established by radio, and they continued radio's advertising business model of single sponsorship, in which advertisers financed and controlled programming, in television broadcasting. In the 196os, however, us commercial television shifted from the radio-era business model towards the network-era model, in which networks took over programme control and sold interstitial minutes for commercials to advertisers. ${ }^{29}$ This shift from single sponsorship towards the new advertising model, called the 'participation format', introduced the 30-second commercial as the standard television advertising format. ${ }^{30}$ According to Cynthia B. Meyers, participating sponsors originally had 6o-second slots, but they began to insert two 30 -second commercials for two different products to economize and efficiently use airtime..$^{31}$ This shift away from single sponsorship towards participating sponsorship formats went hand in hand with a 'creative revolution' in the advertising industry, which was supported by advertisers' investment in high-production-value commercials

27 Ibid., 89 .

28 See ibid., 66.

29 See Cynthia B. Meyers, 'The Best Thing on TV: 196os us Television Commercials', in Films That Sell, ed. Florin, de Klerk, and Vonderau, 173.

$3^{0}$ See Amanda D. Lotz, The Television Will Be Revolutionized (New York: New York University Press, 2007).

31 See Cynthia B. Meyers, 'The Best Thing on Tv: 196os us Television Commercials', in Films That Sell, ed. Florin, de Klerk, and Vonderau, 175 . 
instead of programme development. This 'revolution' included a shift from hard-sell strategies towards soft-sell strategies, the adoption of a more cinematic visual style, the use of countercultural imagery and language, and self-irony. ${ }^{32}$

Returning to the notion of the dispositif, the above-mentioned shift in programming exemplifies how changes in the configuration of one element within the overall programme structure, commercials in this case, reconfigure other elements (economic, structural, aesthetic) and their interplay with each other in the dispositif. Due to the pertinent role of screen advertising in this reconfiguration, the analytical focus examining the television dispositif is on the level of the programme structure.

Williams claims that the insertion of commercials in unsponsored programmes - resulting from the shift from single sponsorship towards participation sponsorship - has had 'extraordinary effects on television as a sequential experience' and has created 'quite new visual rhythms'. Williams sees us television based on the network-era business model as 'a sequence in which the advertisements are integral rather than as a programme interrupted by advertisements'. ${ }^{33}$ Williams promises to discuss this question in more detail, but does not take up the issue later in his book. Yet he emphasizes the 'organic relationship between commercials and other kinds of material', arguing that, due to the sequential and integrating features of television, this 'organic relationship' is much more evident in television advertising than in any earlier systems of advertising. ${ }^{44}$ For Williams, it is this organic relationship between advertising and other broadcast content that makes television advertising qualitatively different from press and poster or display advertising.

Williams's claim that commercials are not an interruption of the flow, but an organic part of it, and his conclusion that commercials, together with trailers and promos, create the flow, are quite notable. Television scholars, and probably most television watchers, usually perceive commercial 'breaks' - the name says it all - as an interruption in the programme. ${ }^{35}$ On the other hand, there is consensus in television studies that interruptions are not a perversion of the viewing experience, but that they define television experience. ${ }^{36}$ For Mary Ann Doane, interruption is crucial to

32 See Ibid., 173-193.

33 Williams, Television, 66-67.

34 Ibid., 68.

35 See, for example, John Fiske, Television Culture (London and New York: Routledge, 1987), 99.

36 See, for example, Jeremy G. Butler, 'An Introduction to Television Structures and Systems: Ebb and Flow in the Postnetwork Era', in Television: Critical Methods and Applications, $4^{\text {th }}$ ed. 
television, because it 'corroborates television's access to the momentary, the discontinuous, the real'. ${ }^{37}$ John Fiske, who speaks of 'the movement of the television text' instead of flow, characterizes this movement as 'discontinuous, interrupted, and segmented': ${ }^{8}$

The television text, then, is composed of a rapid succession of compressed, vivid segments where the principle of logic and cause and effect is subordinated to that of association and consequence to sequence. [...] Its attempts at closure, at a unitary meaning, or a unified viewing subject, are constantly subjected to fracturing forces. 39

For Jeremy G. Butler, television's segmental nature is evident in all types of programmes, but 'peaks in the 30 -second (and shorter) advertisement'. $4^{40}$ In that sense, commercials can be comprehended as the smallest unit both in the organization of network-era television and in the experience of it. How these segments interact with each other and with other television materials in the process of producing meaning has been a major theme in television studies. For John Ellis, the experience of watching advertisements is 'that of seeing segments cluster together, inciting each other. ${ }^{41}$ While their specific meanings have relatively little to do with each other, it is, Ellis argues, 'their generalised generic meanings (a domestic consumerist relation to objects)' that gives them a certain common thematic: "These segments are not made to combine as a montage fragment into a larger organisation of meaning. Thirty seconds by thirty seconds, the "spot" advertisement expands but does not combine'. ${ }^{2}$

However, even seemingly disconnected segments of television's flow may interact with each other semantically, as studies on the relationship between narratives and advertisements have shown. In their analysis of the commercials inserted into an episode of Fantasy Island, Mike Budd, Steve Craig, and Clay Steinman detect clear links between the first commercial of each commercial break and the preceding narrative sequence. This brings them to the conclusion that commercials 'respond fairly directly to the problems, desires and fantasies articulated in the programme's narrative by promising

(New York and London: Routledge, 2012), 12.

37 Mary Ann Doane, 'Information, Crisis, Catastrophe', in Logics of Television, ed. Patricia Mellencamp (Bloomington: Indiana University Press, 1990), 238.

38 Fiske, Television Culture, 105.

39 Ibid.

40 Butler, 'An Introduction to Television Structures and Systems', 13.

41 John Ellis, Visible Fictions: Cinema, Television, Video (London: Routledge, 1992), 118.

42 Ibid., 118-119. 
gratification through products'. ${ }^{43}$ Sandy Flitterman's study on the interaction between commercials and the female narrative of the soap opera, and John Fiske's comparable examination of the relations between commercials and masculine narratives such as The A-Team, produce somewhat similar results. ${ }^{44}$ In both cases, the commercials complement the diegetic world of the narratives. Flitterman argues that commercials are mini narratives that - unlike the narrative of the soap - reach successful closure (at least temporarily); by contrast, masculine narratives, according to Fiske, close with successful achievement, while the commercials inserted frequently highlight the means to that achievement rather than the achievement itself. Thus, for Fiske, the commercials

mediate between the diegetic world of the programme and the world of the viewer - they show that the diegetic world is not complete within itself, but that its boundaries can be broken where it intersects with the 'real' world of the viewer. ${ }^{45}$

Commercials mediate between the world of the diegesis and the 'real' world of the viewers on a semantic level and manage the transition between the two worlds. Jane Feuer has argued that television has three diegetic worlds - that of the programme, that of the commercials and promos, and that of the viewing family - and that these three worlds persistently intersect and interrupt each other..$^{46}$ While I do not deny the experience of commercials interrupting programmes, I suggest that this interruption is rather interpreted as a threshold between two worlds, a transition that is coordinated and orchestrated by commercials. In this sense, commercials act as intermediaries between the world of the programme and the world of the viewers.

In a similar vein, commercials can also be considered intermediaries between different channels, when viewers are triggered to use the remote

43 Mike Budd, Steve Craig, and Clay Steinman, 'Fantasy Island: Marketplace of Desire', in Mass Communication Review Yearbook, vol. 5, ed. Michael Gurevitch and Mark Levy (Beverly Hills: Sage, 1985), 297.

44 Sandy Flitterman, 'The Real Soap Operas: Tv Commercials', in Regarding Television: Critical Approaches - An Anthology, ed. E. Ann Kaplan (Los Angeles: American Film Institute and University Publications of America, 1983), 84-96; John Fiske, 'Gendered Television: Masculinity', in Fiske, Television Culture, 198-223.

45 Fiske, Television Culture, 146-147.

46 Jane Feuer, 'Narrative Form in American Network Television', in High Theory / Low Culture, ed. Colin MacCabe (Manchester: Manchester University Press, 1986), 101-104. 
control to switch channels during commercial breaks. The remote control is yet another factor interrupting the typical television experience, while also serving as a tool for viewers to interrupt the planned flow and switch from the horizontal axis of a single linear programme to other channels and the vertical axis of programming, thus producing their own flow. But interruptions in the programme, I argue, following Williams, are not necessarily interruptions of the flow. Rather, they are essential parts of it in that they help create the flow.

Viewers can interrupt television's flow not only with the help of the remote control or later viewing technologies such as the video recorder. They can interrupt television consumption by leaving the room, by turning away from the screen, or by simple inattention. The dispositif of television does not position the viewer as tightly as the dispositif of cinema, for the spatial relations in television viewing differ significantly from the viewing position in cinema. The TV set in the network era, as many scholars have pointed out, is an ambient component of the domestic space, and television programming is structured according to the daily routine with specific time frames for children, women, and the family to watch TV. At the same time, television's schedule structures daily routines both temporally and spatially in a normative way. Television viewers are frequently engaged in other activities such as household work, and have therefore been considered 'intermittent viewers'. ${ }^{47}$ Intermittent viewing is in stark contrast - at least in theory, but not necessarily in practice, as we have seen - to the captive spectator in cinema. As a consequence, television constantly struggles for viewers' attention. The segmented structure that television adopted is a means to pare television down into small portions to encourage viewer engagement. From this perspective, as the smallest unit of television, commercials can somewhat paradoxically be regarded as the smallest element in television's strategy to direct audience engagement and maintain viewer attention. ${ }^{48}$

47 Tania Modleski, 'The Rhythms of Reception: Daytime Television and Women's Work', in Regarding Television, ed. Kaplan, 67-75.

48 Given the focus of this chapter on movement, I exclude the crucial role of television audio as an ambient aural component of the domestic space. For how television audio manipulates and commodifies inattentive audiences by sustaining, focussing, and directing audience engagement in network television, see Rick Altman, 'Television/Sound', in Studies in Entertainment: Critical Approaches to Mass Culture, ed. Tania Modleski (Bloomington: Indiana University Press, 1986), 39-54; John Ellis, 'Broadcast TV as Sound and Image', in Film Theory and Criticism: Introductory Readings, ed. Gerald Mast, Marshall Cohen, and Leo Braudy (New York: Oxford University Press, 1999), 385-394. Altman argues that television sound mediates the relationship between 'household flow' and 'programming flow'. For an overview of television sound studies and developments 


\section{The Place and Role of Commercials in Public Service Broadcasting}

Television's flow is a matter of degree, however. The previous description of the place and role of commercials in television programming applies to a business model that is based on advertising. In this model, according to Butler, 'programmes are just filler, a necessary inconvenience interrupting the true function of television: broadcasting commercials' ${ }^{49}$ As Rick Altman has pointed out, the extent of flow is related to television's economic context; flow both endorses and is exploited by commercial interests of television. ${ }^{0}$ While network-era television in the United States strongly relied on flow, public service broadcasting in Western Europe even today shows a much lesser degree of flow. The extent of flow depends on the financing model of broadcasting: while commercial TV channels in Europe also heavily promote flow (within the regulatory framework in which they operate), ${ }^{51}$ public-service television stations still strongly rely on discrete programming. This is particularly evident in the case of advertising. Ever since the inclusion of commercials in public service broadcasting, and even before, the place of advertising in public-service programmes has been highly contested and subjected to strict regulations. In Germany, for example, where advertising became part of public-service television in 1956, the broadcasting of commercials on channels such as ARD and ZDF is at present restricted to a yearly average of 20 minutes of advertising on workdays before 8:00 p.m. On Sundays and on national holidays, advertising is not allowed. The broadcasting of commercials is also restricted to block advertising. ${ }^{52}$ This means that commercials of 10 , 15, 20, or more seconds in length are broadcast only in commercial blocks and as a general rule are inserted in 'natural' programme breaks, that

in the field that take into account recent technological developments, see Carolyn Birdsall and Anthony Enns, 'Editorial: Rethinking Theories of Television Sound', Journal of Sonic Studies 3, no. 1 (October 2012), https://hdl.handle.net/11245/1.377378 (last accessed 6 April 2021).

49 Butler, 'An Introduction to Television Structures and Systems', 13.

50 Altman, 'Television/Sound'.

51 See 'Fact Sheets on the European Union: Audiovisual and Media Policy', http://www.europarl. europa.eu/atyourservice/en/displayFtu.html?ftuId=FTU_3.6.2.html (last accessed 6 April 2021). An update of the regulatory framework of the 'Audiovisual Media Services Directive' (AVMSD) was launched in 2015 that proposes to change the limit for commercial communications from 12 minutes per hour to 20 per cent of the time between 7:00 a.m. and 11:00 p.m. EU Parliament and the Council are currently reviewing the proposal (ibid.).

$5^{2}$ http://www.ard.de/home/intern/fakten/abc-der-ard/Rundfunkwerbung/553184/index. html (last accessed 6 April 2021). 
is, between when one programme unit finishes and another one begins. Importantly, commercials must also be clearly marked as advertising and be separated from other elements of the programme with the help of visual or acoustic signals..$^{53}$ And not only is the commercial block separated from the rest of the programme, the commercials within the block are themselves separated from one another through cartoons or stills. ${ }^{4}$ Hence, the shift from the concept of sequence as programming to the concept of sequence as flow that Williams observed in 1974 has not been nearly as complete and comprehensive as postulated. Programming has been much more complex and diverse. Deregulated or subject to national and/ or supranational regulations (as in the case of the European Union), TV programmes reflect historically specific economic and political interests that have also affected the place and role of advertising.

To better understand the specific place of screen advertising in public service broadcasting in Western Europe from its beginnings, we can take as an example the first commercial 'break' ever aired on Swiss German television, on 1 February $1965 \cdot 55$ Fortunately, the entire commercial block has been archived by Swiss television, although the programme elements that preceded and followed it were not. ${ }^{56}$ The mini programme of commercials begins with a cartoon bumper that separates the commercials from the rest of the programme; its credit title 'Telespot' makes explicit that what follows is advertising. Thus, advertising is unmistakably marked as advertising. The cartoon features two figures: a child, presumably a boy, and a bearded man. The latter intends to take a photograph of the boy sitting in front of him on a swivel chair, and presses the flash button, but nothing happens. When the man inspects

53 'ARD-Richtlinien für Werbung, Sponsoring, Gewinnspiele und Produktionshilfe in der Fassung vom 12.03.2010', 2, http://www.ard.de/download/553234/ARD_Richtlinien_fuer_Werbung__Sponsoring__Gewinnspiele_und_Produktionshilfe_in_der_Fassung_vom_12_3_2010. pdf (last accessed 6 April 2021).

54 http://www.ard.de/home/intern/fakten/abc-der-ard/Rundfunkwerbung/553184/index. html (last accessed 6 April 2021). In 2012, broadcasting (both radio and television) advertising and sponsorship contributed six per cent to the total revenue of state broadcasting in Germany (ibid.).

55 In Switzerland, it took nine more years of negotiations than in Germany before commercials were granted a permanent place in public broadcasting. At that moment, no commercial channels existed in either Germany or in Switzerland; commercial television stations in Europe increased in the 1980 s due to new developments in broadcasting technologies and the introduction of the dual broadcasting system.

56 See André Hofer, 'Schon 20 Jahre TV-Werbung!', in TV Transit Express: AG für das Werbefernsehen (Bern, January 1985), n.p. 
the flash, it flashes the photographer, making his eyes spin in circles (see Figures 5.1 and 5.2 ). This intro is followed by eight commercials in total for the following brands:

- Ovomaltine (Ovaltine) by Wander, a milk flavouring product usually made with malt extract, sugar (if not in Switzerland), whey, and, originally, eggs;

- Via and Radion detergents, a cartoon advertising two products on promotion;

- Chocoletti by Lindt, a stop-motion animated picture;

- Opel Kadett, a car model that, as the slogan has it, first of all would have to please Yvonne;

- Maggi pea soup with speck, making suggestions for 'light meals' such as Maggi pea soup with speck and sausages;

- Union Bank of Switzerland, featuring a testimonial from an elder man in a suit, tie, and hat sitting with friends on a terrace in Ascona at the shore of Lago Maggiore getting ready for a boat trip with a young woman;

- Pepsi-Cola, somewhat the continuation of the preceding commercial in that a group of young people have fun in a car that drives on water;

- Jubilor coffee by Coop, another animated picture.

The total length of the commercial break is five minutes and it is in standard black and white. ${ }^{57}$ The commercials are clearly separated from one another through the insertion of silent kaleidoscopic images between the commercials that display white lines against a black background merging into ever changing formations (see Figures 5.3 to 5.17). The commercial block closes with a continuation of the cartoon bumper that opened it. The photographer is still about to take a picture of the child, but this time, the child turns over the flash and directs it towards the camera lens so that the photographer gets flashed again when he pushes the button. The commercial break closes with the same 'Telespot' logo with which the programme opened (see Figures 5.18 to 5.20).

Obviously, the structure of the mini programme of commercials is that of a series of sequentially timed units in which the boundaries between even the smallest programme units, the commercials, are visually and acoustically (through silence) marked, thus creating discrete and distinctive intervals instead of a flow. The 'organic relationship' between commercials and other parts of the programme that Williams emphasizes is disrupted

57 Even though the technology was available starting in the 1950s, colour television became standard only in the 1970s. 

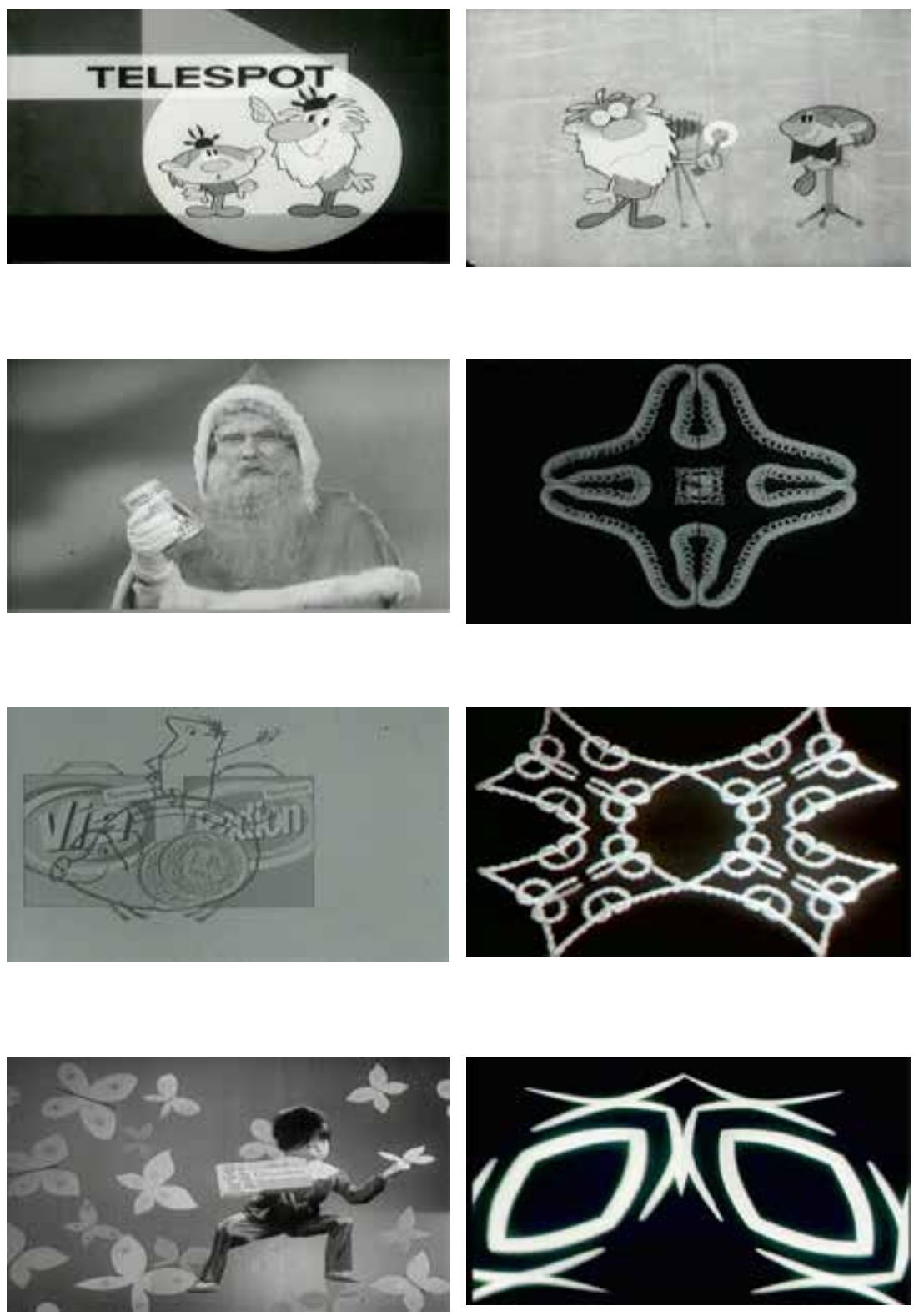

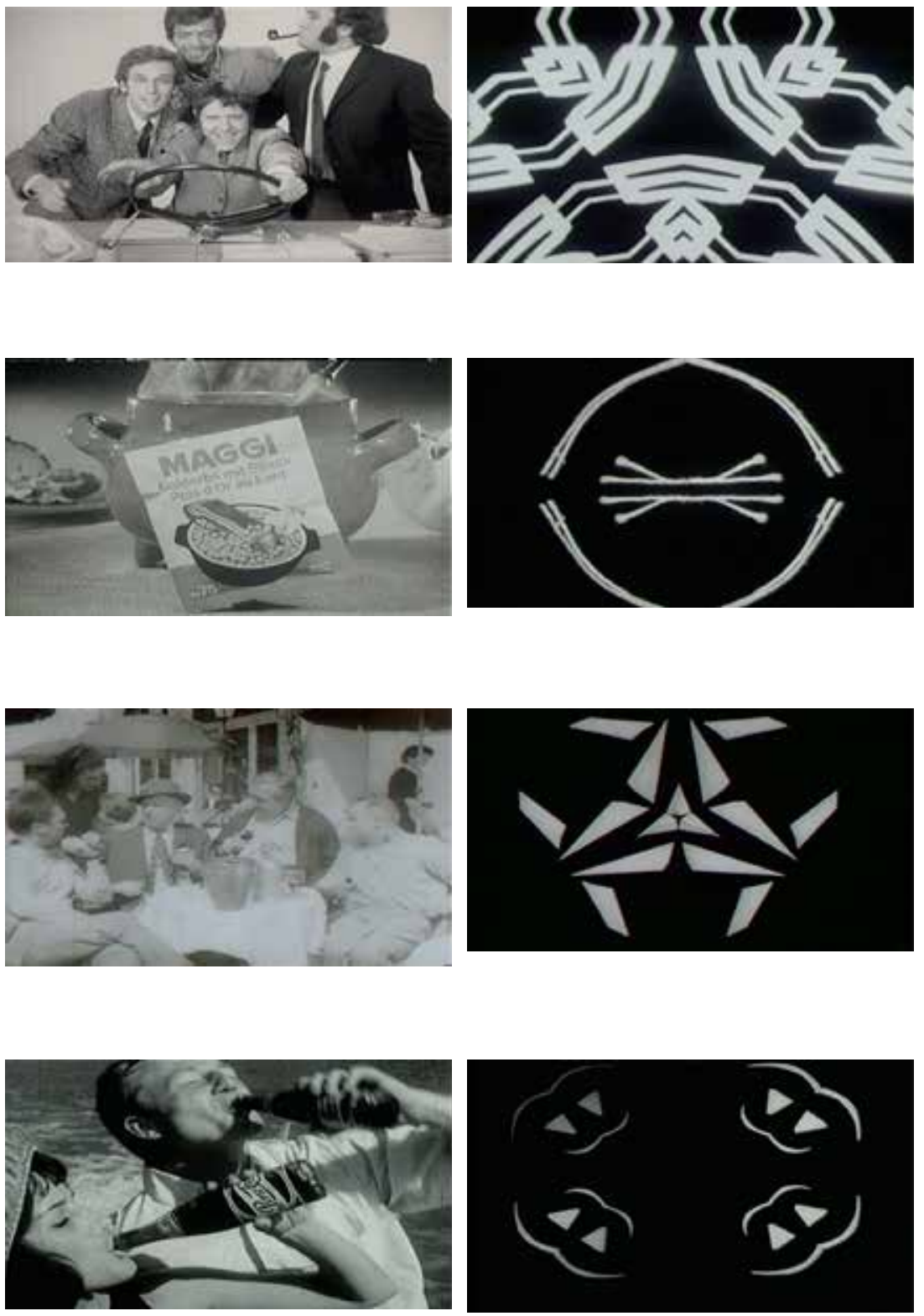

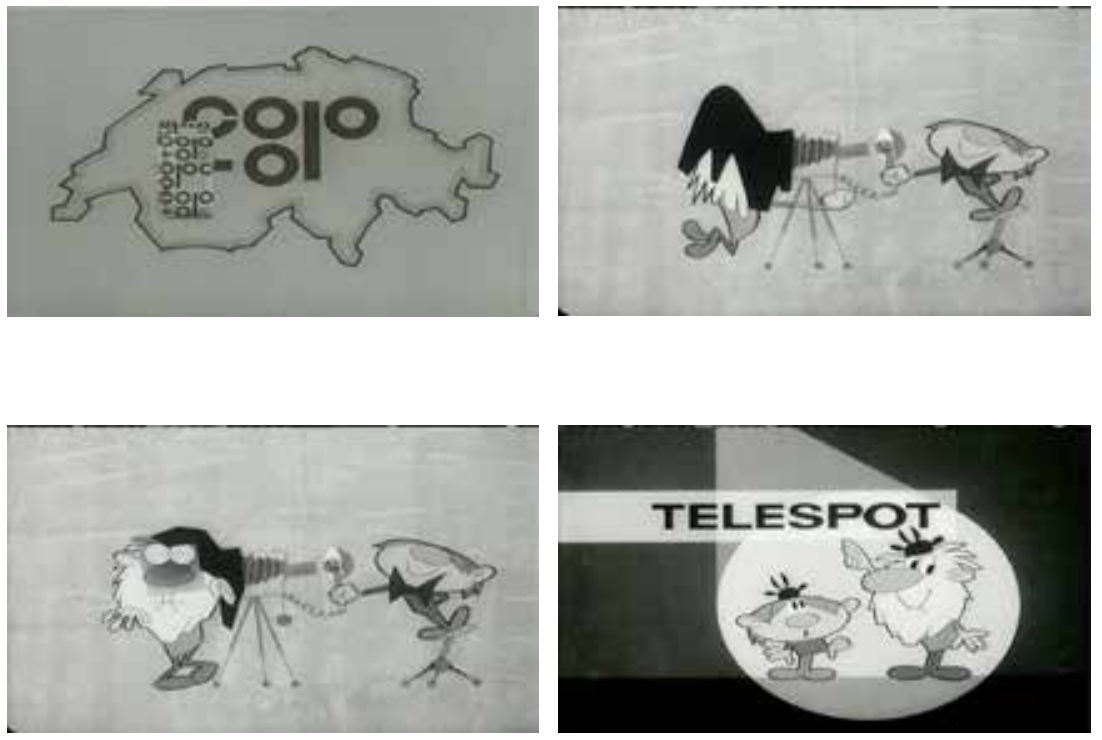

Figure 5.1-5.20: Screenshots from the first commercial 'break' aired on Swiss German television, on 1 February 1965.

in this example by clear-cut markers of boundaries both between programme units and between individual elements within the programme unit. However, this does not preclude that connections can be drawn between commercials, here most obviously between the Union Bank and the Pepsi-Cola commercial, with the latter somewhat continuing the story of the former.

Some peculiarities in the commercial break deserve mentioning. The opening Ovomaltine commercial features Santa Claus, who specifically addresses children and announces in Swiss German that Ovomaltine boxes are now - in early February (!) - coming with arts-and-crafts sheets for Christmas decoration. While the vast majority of the commercials are plain, simple, of low production value, and hard sell, the Pepsi Cola commercial stands out from the rest of the advertising programme for its cinematic visual style, its framing and fast and rhythmic editing pace - a prime example of the 'creative revolution' in the us advertising industry. As such, the commercial break internalizes tensions between the national specificity of television, the vernacular, and the international in the form of us popular culture: the national specificity resides in television's organization and regulation, but also in its addressing German-speaking 
Switzerland (one of four official national language communities) in High German as a national audience. By contrast, Santa Claus's Swiss German dialect in a deep voice creates the intimate homelike atmosphere of the vernacular. Finally, the Pepsi-Cola commercial breathes the spirit of us youth and pop culture. In that respect, the chronological order of the commercials is notable: it begins with the vernacular, which is closest to the world of the viewers and which serves to introduce them to the new world of screen advertising on Swiss television, and it ends with a commercial that promotes Coop's coffee (of all products!) as a national product, the pack shot showing the coffee package and trademark embedded within a drawing that represents the shape of Switzerland (see Figure 5.17). In this way, the international feel of the penultimate commercial, the Pepsi-Cola commercial, is repatriated, so to speak, and the nation-building public-service mission accomplished - with the help of advertising.

The regulatory framework that insists on marking commercial breaks as separate from other parts of the public service broadcast programme has had some unexpected side effects. Some cartoon bumpers - if not the one in the Swiss example mentioned above - have become cult. In Germany, the cartoon series 'Äffle und Pferdle' (Ape and Horse), which aired on the South German broadcasting service starting in 1960, and 'Mainzelmännchen' (Manikins from Mainz), which aired on zDF from the beginning of the station in 1963, are still very popular on television and have been enjoying a vibrant second and third life on DVD and on YouTube (see Figures 5.21 and 5.22). ${ }^{8}$ The bumpers, a regulatory tool to separate commercials both from other parts of the programme and from other commercials, in today's television practice very often connect the commercial block with preceding programme material as well as commercials with each other rather than separating elements from one another. Bumpers such as 'Mainzelmännchen' often interact with the programme content and the content of commercials by way of picking up on themes and motifs of preceding programmes or commercials, thus mimicking, commenting on, and sometimes even parodying television material, thereby adding a self-reflexive level to advertising and television

$5^{8}$ I particularly recommend for viewing the 'Hafer und Bananenblues' (Oat and Banana Blues) from the 'Äffle und Pferdle' series: https://www.youtube.com/watch?v=7FyaEEMRY_A (last accessed 6 April 2021). For 'Mainzelmännchen', see: https://www.youtube.com/results?search_ query=mainzelm\%C3\%A4nnchen (last accessed 6 April 2021). For international bumpers on YouTube, see: https://www.youtube.com/results?search_query=bumpers (last accessed 6 April 2021). 


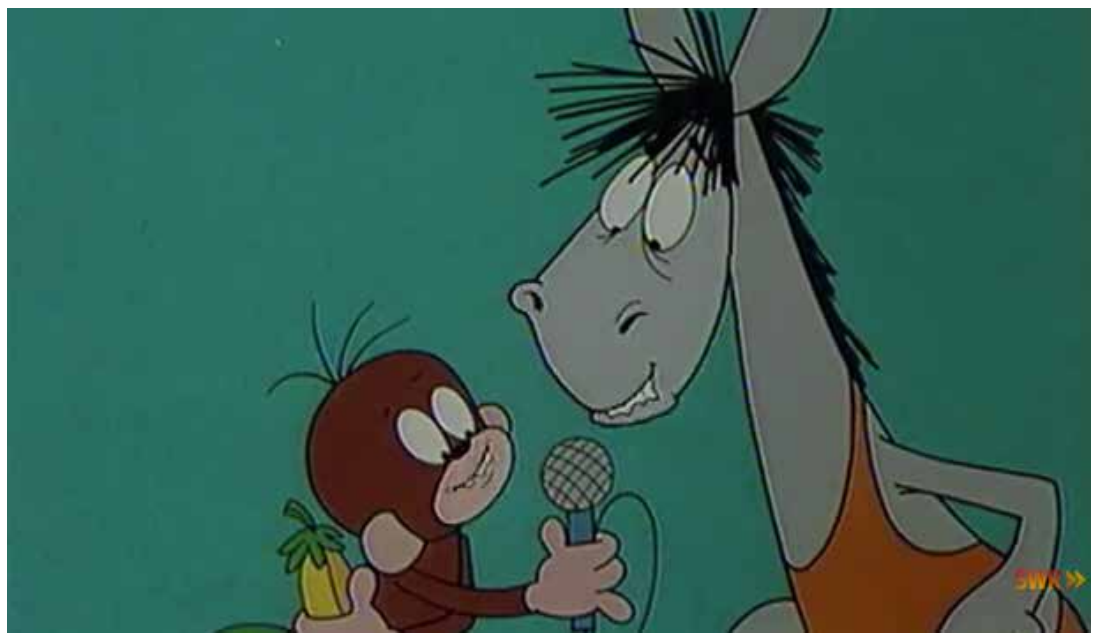

Figure 5.21: Screenshot from the cartoon series 'Äffle und Pferdle' (Ape and Horse).

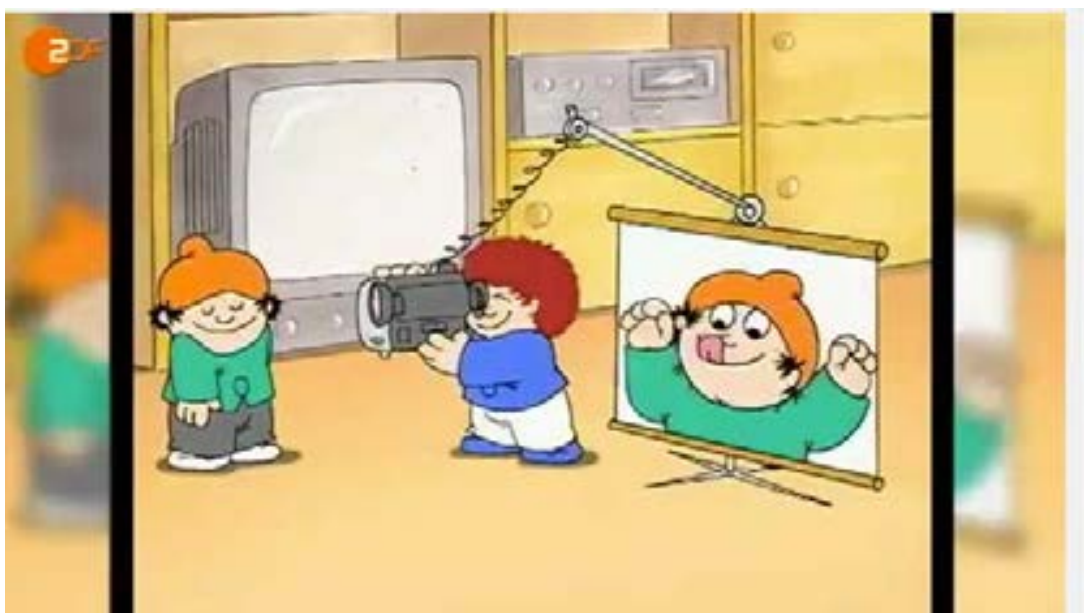

Figure 5.22: Screenshot from 'Mainzelmännchen' (Manikins from Mainz).

programming in general. Despite strict regulations to separate commercial blocks from the rest of the programme and to clearly mark advertising as advertising, it is of all things the markers themselves - that is, the cartoon bumpers - that establish connections between distinctive programme units, thus stitching the programme together. It can be concluded then 
that, in contemporary public service broadcasting, commercials, with the help of bumpers, work as intermediaries between programme units, thus managing transitions rather than signalling an interruption in the programme 'flow'.

\section{Moving Images - Visual Mobility}

The development of interactive viewing technologies such as digital video recorders and online video has complicated the idea that Williams's concept of flow developed for network-era television can explain television in the post-network era. But what television studies can still take from Williams is his insistence that media texts are not to be considered in isolation as textual entities, but rather that we focus on how these texts connect and interact with other texts, institutions, technologies, and practices. ${ }^{59}$ While this chapter is in line with Williams's focus on the relational dimensions of screen advertising, I wish to pick up on yet another point that Williams makes in 1974 and that has been rather neglected, if not repudiated altogether by television studies. Thinking about the innovative forms of television, Williams considers television itself as an innovative form, because it provides new experiences of seeing. To get this kind of attention, Williams suggests that we turn off the sound, which often directs attention to content: 'What then can happen, in some surprising ways, is an experience of visual mobility, of contrast of angle, of variation of focus, which is often very beautiful. ${ }^{60}$ Williams insists that this aesthetic experience of visual mobility is not a by-product of some other experience, but 'one of the primary processes of the technology itself, and one that may come to have increasing importance. ${ }^{61}$

Pioneering television sound studies by Rick Altman and John Ellis in the 1980s, however, glossed over Williams's idea of television's genuine visuality, arguing that television is closer to radio than to film and that sound is more important than images in television. ${ }^{62}$ Building on Altman and Ellis's work, Michel Chion in the 199os claimed that 'television is fundamentally a kind of radio, "illustrated" by images', which brought him to the conclusion

59 Michael Kackman et al., eds., Flow Tv: Television in the Age of Media Convergence (New York and London: Routledge, 2011), 2.

6o Williams, Television, 75 .

61 Ibid., 76 .

62 Altman, 'Television/Sound'; Ellis, 'Broadcast TV as Sound and Image'. 
that 'silent television is inconceivable' ${ }^{63}$ - a view that has been seriously challenged by the increasing practices of silent TV watching in public places. While the idea of television as 'illustrated radio' has become the basis of television sound studies for several decades, it was John Caldwell who questioned in the mid 199os the persistent notion that television privileges the ear, whereas film privileges the eye, pointing to television's 'obsession with making images that spectacularize, dazzle, and elicit gazelike viewing. ${ }^{64}$ The production, distribution, and reception of television has significantly changed in recent years (with the rise of home entertainment systems, widescreen televisions, $3 \mathrm{D}$ technology, out-of-home television, digital television networks, mobile media, etc.) and has triggered television sound studies to rethink earlier approaches to television sound. ${ }^{6}$ In light of this current development, Williams's insistence in 1974 that television's innovative form resides in providing 'an experience of visual mobility' is even more remarkable.

\section{Out-of-Home Advertising with Infoscreens}

Moving from network-era home television to today's out-of-home advertising screens, I bring along Williams's notion that moving images provide an experience of visual mobility when examining a media dispositif in a public space that is both structuring and structured by the relational contingencies between mobility and immobility, between movement and arrest. In the following discussion, train platforms in Germany serve as an exemplary case to study the place and role of screen advertising in out-of-home media dispositifs. I draw predominantly on literature from mobilities studies, which developed within the social sciences in the course of a mobility 'turn' in the 199os. The contemporary mobilities paradigm as it originated in the work of sociologist John Urry in 2000 is devoted to the examination of diverse mobilities of peoples, objects, images, information, and wastes, and the interdependencies between

63 Michel Chion, Audio-Vision: Sound on Screen, ed. and trans. Claudia Gorbman (New York: Columbia University Press, 1994), 165.

64 John T. Caldwell, Televisuality: Style, Crisis, and Authority in American Television (New Brunswick: Rutgers University Press, 1995), 158.

65 See Journal of Sonic Studies 3, no. 1 (October 2012), a special issue dedicated to rethinking theories of television sound. 
these different kinds of mobilities. ${ }^{66}$ I wish to bring this sociological approach into dialogue with attempts in media and communication studies to re-examine the notion of flow in an increasingly mobile media environment in which digital screens can no longer be understood in terms of medium specificity. According to Kathleen Oswald and Jeremy Packer, such a reconsideration of flow 2.0 includes a shift in attention from the programming of content in a sequence for a single device towards 'the programming of a fluidly scheduled mobile life via networked terminals and mobile devices'. ${ }^{67}$ The question of flow thus becomes one of how the use of multiple screens, fixed and mobile, 'orchestrate the individual's material flow through space according to a fluid set of temporal programmes'. ${ }^{68}$

My point of departure to examine screen advertising's place in flow 2.0 are so-called Infoscreens: large digital screens on busy subway and suburban train station platforms as well as at long-distance train stations. These screens belong to a long and contested history of out-of-home media displays that can be traced back to ancient Rome's painted or carved wall inscriptions that were meant to attract attention. ${ }^{69}$ Reproduction technologies such as Johannes Gutenberg's invention of movable type printing in $145^{\circ}$ and the invention of lithography in the late 1790s gave rise to handbills and illustrated posters, respectively. Out-of-home advertising proliferated and was institutionalized in the nineteenth century. As Erkki Huhtamo, in his media archaeology of public media displays unearths, placard advertising was realized early at railway stations - for the same reason train stations, airports, and other transit zones are privileged advertising locations today: 'The constant flow of passers-by made them attractive'. ${ }^{70}$ Since the instalment of the first digital billboards in $2005^{71}$ and the replacement of traditional billboards with dynamic LED

66 See John Urry, Sociology Beyond Societies: Mobilities for the Twenty-First Century (London: Routledge, 2000).

67 Kathleen Oswald and Jeremy Packer, 'Flow and Mobile Media: Broadcast Fixity to Digital Fluidity', in Communication Matters: Materialist Approaches to Media, Mobility and Networks, ed. Jeremy Packer and Stephen B. Crofts Wiley (London and New York: Routledge, 2012), 279.

68 Ibid. 277.

69 Erkki Huhtamo, 'Messages on the Wall: An Archaeology of Public Media Displays', in Urban Screen Reader, ed. Scott McQuire, Meredith Martin, and Sabine Niederer (Amsterdam: Institute of Network Cultures, 2009), 15-28, here 16.

70 Erkki Huhtamo, 'Messages on the Wall: An Archaeology of Public Media Displays', in Urban Screen Reader, ed. Scott McQuire, Meredith Martin, and Sabine Niederer (Amsterdam: Institute of Network Cultures, 2009), 18.

71 See Outdoor Advertising Association of America (OAAA), 'History of ooH', https://oaaa.org/ AboutOOH/OOHBasics/HistoryofOOH.aspx (last accessed 6 April 2021). 
billboards, digital out-of-home advertising has massively proliferated. In the United Kingdom, for example, the number of digital screens has increased from 2056 in 2009 to over 17,000 in $2017 .^{2}$ According to the value proposition of Outdoor Advertising Association of America (OAAA), the leading trade association representing the out-of-home advertising industry in the United States founded in 1891, out-of-home advertising has gained in importance and effectiveness once again in the age of digital and social media:

In a world of clicks, likes, and page views, out of home (OOH) advertising is more of a core media buy than ever before. $\mathrm{OoH}$ is the real thing. It can't be blocked, skipped, or viewed by bots. оOH is always on, surrounding and immersing audiences with the real, powerful, advertising, wherever consumers live, work, travel, shop, and play. ${ }^{73}$

Back in Germany, Infoscreen GmbH was founded in 1991 in Nuremberg and installed its first Infoscreen system at Odeonsplatz station in Munich in 1994. Infoscreen $\mathrm{GmbH}$ is a Ströer subsidiary; Ströer is a stock market-listed German company operating on an international level to market out-of-home advertising. The company is one of the largest providers of out-of-home media in German-speaking countries (with the umbrella company's sales reaching $€_{1.33}$ billion by the end of 2017) ${ }^{74}$ specializing in digital out-of-home advertising at high-frequency touchpoints. Infoscreen $\mathrm{GmbH}$ operates five different place-based advertising media: Infoscreen (which I will examine in more detail in the following), mall video, station video, super motion (i.e., large screens in highly exposed locations in public spaces), and Dus ad walk (i.e., five displays coordinated in walking areas such as airports that make one series of images). In 2017, the company operated approximately 300,000 out-of-home advertising media in total..$^{75}$ According to the company's website, Infoscreen is currently present in eighteen cities in Germany, with a total of 506 screens. ${ }^{7}$ Since 1997 , Infoscreen also operates in Austria; since

72 Nick Hammond, 'Why Digital Out-of-Home Advertising Is not Really Digital (Yet)', 9 October 2017, https://www.econsultancy.com/blog/69491-why-digital-out-of-home-advertising-isnot-really-digital-yet (last accessed 6 April 2021).

73 See Outdoor Advertising Association of America (OAAA), 'оoн Value Proposition', https:// oaaa.org/AboutOOH/OOHBasics/OOHValueProposition.aspx (last accessed 6 April 2021).

74 https://www.stroeer.com/unternehmen/profil/auf-einen-blick.html (last accessed 6 April 2021).

75 https://www.stroeer.com/unternehmen/profil/auf-einen-blick.html (last accessed 6 April 2021).

76 https://www.infoscreen.de/en/plan-calculate/media-locations/ (last accessed 21 March 2018). 


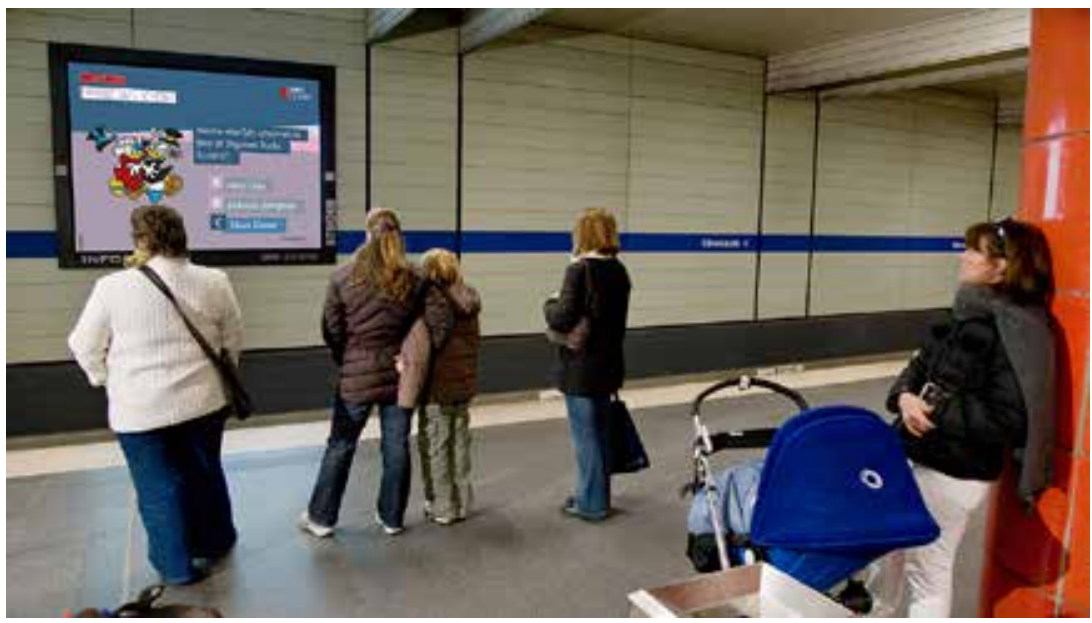

Figure 5.23: Infoscreen at Munich Odeonsplatz (Infoscreen).

2003, Infoscreen has been owned by Gewista Werbegesellschaft $\mathrm{GmbH}$, which is a group company of JCDecaux, the world's largest out-of-home advertising company. ${ }^{77}$ Infoscreen Austria currently operates 48 screens in stations in Vienna and over 2500 screens in trams and buses in Vienna, Graz, Linz, Innsbruck, Klagenfurt, and Eisenstadt. ${ }^{7}$

In Germany, Infoscreens (aspect ratio: 4:3, resolution: 1024 x 768 pixel) operate daily from 6:00 a.m. to midnight. They are placed on (partition) walls that passengers face while waiting on train platforms, the tracks spatially separating commuters from Infoscreens. The programme is structured in a loop that repeats itself every ten minutes and consists of a mix of editorial and advertising content, with commercial length varying from 5 to 30 seconds. The screens are silent; therefore, there is only visual, no aural, interaction between screens and (potential) onlookers possible. Aural interactions come from loudspeakers announcing arriving and departing trains. For this reason, the commercials are often adapted from posters and other still artwork (which communicate without sound), lending them the character of animated signage. ${ }^{79}$ The editorial content, which is said to be at least 60 per cent, ${ }^{80}$ includes news, weather reports,

77 http://www.infoscreen.at/infoscreen/impressum/ (last accessed 21 March 2018).

78 http://www.infoscreen.at/werben/mediaplaner/ (last accessed 21 March 2018).

79 In a short video on its website, Infoscreen gives an example of how a poster can be adapted to an animated Infoscreen spot. See https://www.infoscreen.de/en/our-media/infoscreen/ production/ (last accessed 21 March 2018).

80 https://www.infoscreen.de/en/our-media/infoscreen/ (last accessed 21 March 2018). 
and trivia organized in recurring categories such as 'Geschmackssache' (Question of Taste) for recipes, 'Zitiert' (Quoted) for quotes by famous people, 'Warten \& Raten' (Waiting and Guessing) for quiz questions, 'Zahlen, bitte' (Numbers, Please) for amazing numbers, and 'Fun Factor' mostly for sports activities (Figure 5.23). The transitions from editorial to advertising content are unmarked and the programme is sequentially structured to create a flow of images typical for screens whose raison d'être is advertising.

\section{Screen Advertising While You Wait}

Infoscreen advertises itself to potential customers as an advertising tool that gets 'a lot of attention in the low-stimulus public space: your target group is grateful for the change of pace that your advertising provides in the waiting situation. During the average five-minute wait even longer messages can be taken in'. ${ }^{81}$ In a similar vein, the Ströer media data info sheet claims that

Infoscreens catch the audience's eye with an attractive range of the latest information, entertainment, and advertising, ensuring widespread reach in the process. The unique opportunities for advertising while commuters wait for their trains are guaranteed to grab the target audience's attention and provide high-impact advertising. Infoscreens are not perceived as a form of advertising, rather as a familiar companion for the target audience as they travel through the city. ${ }^{82}$

Infoscreen can be regarded as somewhat similar to what Anna McCarthy termed 'television while you wait': like out-of-home television, Infoscreens accompany - and commodify - the act of waiting, which, to use McCarthy's words, foregrounds 'the centrality of time, and environmental rhythms, in the processes through which television and TV images interweave with the habitual atmospheres of social space'. ${ }^{83}$ While McCarthy examines how TV sets regulate the flow and experience of time, I wish to take into

81 https://www.infoscreen.de/en/our-media/infoscreen/ (last accessed 21 March 2018).

82 Ströer Media Data, 'Campaign Media Digital: Infoscreen' (January 2017), 2. Last accessed 21 March 2018; no longer available online. For Ströer Media Data 2021 on Infoscreen and DOOH, see https://www.stroeer.de/fileadmin/regional/wt_downloads/9395.pdf?Mediadaten\%2o Infoscreen\%202021.pdf (last accessed 23 March 2021).

83 Anna McCarthy, Ambient Television: Visual Culture and Public Space (Durham, NC and London: Duke University Press, 2001), 195. 
consideration the relational dynamics between the movements of images, people, and objects with which Infoscreens are interlocked. The media dispositif of train platforms is, as mentioned earlier, characterized by a constant flow of passers-by who may - or may not - glance at the public screens or may prefer to interact with their own private mobile screens. At the same time, frictions in flows, immobilities, standstills, and dwellings constitute the dispositif. Train platforms are transit zones, but they are also waiting zones, non-lieux (non-places) in French anthropologist Marc Augé's description. ${ }^{84}$ The aspect of waiting is emphasized both by McCarthy and by Infoscreen's self-promotion. Obviously, waiting is an interruption: on platforms, the flow of bodies is temporarily halted, and bodily movement is reduced to small-scale on-site movements. As in the dispositifs of cinema and network-era television, interruption (here, the temporary suspension of corporeal movement) is the very moment screen advertising comes into play. On platforms, as in cinemas, while the movement of bodies is suspended, the movement of images on the screen continues the flow of movement, with advertising coordinating and orchestrating the transition between the different types of movements, thus stitching together the flow of bodies with the flow of images and the flow of objects.

The latter becomes evident when looking at how the rhythms of Infoscreens are synchronized with the rhythms of trains arriving and departing. The programme of Infoscreen may be organized in a loop repeating itself every ten minutes. The experienced temporalities of Infoscreens on the platform, however, are different, as a result of a harmonization of the movements of bodies and images and the mobilities of public transport: shortly before a train arrives at the platform, which is announced over the loudspeakers, Infoscreen's programme disrupts and the screen goes still and nearly blank, announcing in white letters that 'Zug fährt ein!' In the next line, in slightly smaller characters, is the same message in English - namely, 'Train arriving!' At the top of the screen, the city train logo can be seen (Figure 5.24). ${ }^{85}$ The flow of images stops when a train arrives that picks up on the movement of the images and continues the flow.

The dispositif of train platforms equipped with Infoscreens is temporally structured by intermittent movements - of bodies, images, and objects. If television viewers have been conceived as intermittent viewers, here, all

84 Marc Augé, Non-Places: An Introduction to Supermodernity, trans. John Howe (London: Verso: 2009 [1992]).

85 This description refers to the scenario at a suburban train platform at Frankfurt central station on 11 March 2017. 


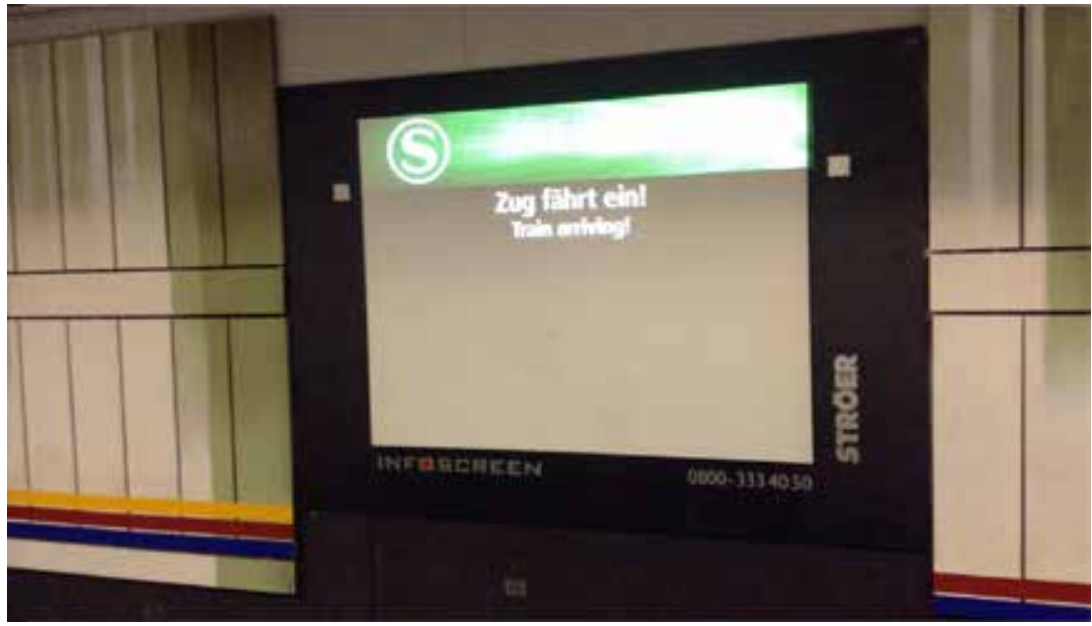

Figure 5.24: Infoscreen at Frankfurt central station, 2017 (photo by author).

movements and mobilities can be considered temporarily intermittent. In that sense, Infoscreens are part of a dispositif that Sheller and Urry describe as 'immobile infrastructures that organize the intermittent flow of people, information, and image'. ${ }^{86}$ Thus, a complex interlocking of mobility and mooring systems characterizes the media dispositif of train stations equipped with Infoscreens and testifies to an intricate coordination between transport and communication. This coordination 'mobilizes' the requirements and characteristics of co-presence 'into a new kind of mobility nexus', according to Kevin Hannam, Sheller, and Urry. ${ }^{87}$

While mobility studies have focussed on the relational contingencies between mobility and immobility and have considered the mobility of one as being at the expense of the immobility of another, ${ }^{88}$ David Bissell, in 'Animating Suspension: Waiting for Mobilities', suggests a new focus on the corporeal experience of the event of waiting during travel that considers waiting not through the relationality between mobility and immobility, but through the relationality between activity and inactivity: ${ }^{89}$

86 Mimi Sheller and John Urry, 'The New Mobilities Paradigm', in Environment and Planning A 38 (2006): 212 .

87 Kevin Hannam, Mimi Sheller, and John Urry, 'Editorial: Mobilities, Immobilities and Moorings', Mobilities 1, no. 1 (March 2006): 4.

88 See Peter Adey, 'If Mobility Is Everything then It Is Nothing: Towards a Relational Politics of (Im)mobilities', Mobilities 1, no. 1 (2006): 75-94.

89 David Bissell, 'Animating Suspension: Waiting for Mobilities', Mobilities 2, no. 2 (July 2007): $277-298$. 
Contrary to thinking through the event of waiting as a slowed rhythm, perhaps it does take effort and therefore some form of intentional action to wait. In other words, for the body to be immobile, it is still primarily pursuing an active purposive role of making-of-the-world and maintenance of meaning. In many ways, an active doing of waiting and how a subject comes to wait could be seen as an achievement of a specific set of ongoing embodied tasks. These might include the agentive capacity of making decisions of where to wait and what to do while waiting..$^{\circ}$

Waiting, from this perspective, is a chasm, a temporal void of 'dead time', in Joe Moran's words, ${ }^{91}$ or 'empty intervals between instants', in Harold Schweizer's, ${ }^{92}$ to be filled somehow with activity. Bodily stasis during periods of waiting, Bissnell and other have argued, heralds a heightened corporeal attentiveness and sensual responsiveness to the immediate environment, and produces a different kind of 'relationality from relation-in-the-world towards a relation-to-the-word'. 93

The idea that waiting involves heightened responsiveness is also the sales pitch for Infoscreen, which, as mentioned before, claims that, while travellers wait, advertising is guaranteed to grab their attention, for commuters are 'grateful for the change of pace' that advertising provides in the waiting situation. The company's English slogan 'We Get People Watching' - 'Wir machen Hingucker zu Zuschauern' in German ${ }^{94}$ - refers to the particular relation-to-the-world in waiting, in which heightened attentiveness and responsiveness stimulate a shift from coincidental glancing towards attentive gazing. In this particular dispositif, Infoscreens may temporarily position the immobilized bodies of commuters in front of the screen and turn passers-by into spectators.

Clearly, screen advertising exploits this perceptive environment while people wait. At the same time, as Bissell has suggested, we can also think of some of the numerous activities that are enacted while waiting as 'a method of harmonising' the different temporalities of stasis and mobility during periods of waiting. ${ }^{95}$ From this perspective, screen advertising can

90 Ibid., 285 .

91 Joe Moran, 'November in Berlin: The End of the Everyday', History Workshop Journal 57, no. 1 (Spring 2004): 218.

92 Harold Schweizer, 'On Waiting', University of Toronto Quarterly, no. 3 (2005): 789 . See also Barry Schwartz, Queuing and Waiting: Studies in the Organization of Access and Delay (Chicago: University of Chicago Press, 1975).

93 Bissell, 'Animating Suspension', 287.

94 https://www.infoscreen.de/en/ and https://www.infoscreen.de (last accessed 21 March 2018).

95 Bissell, 'Animating Suspension', 290. 
be comprehended as a mediator between different temporalities, one that acts as a temporal intermediary between mobility and immobility and that organizes the relational contingencies between mobility and immobility. In this way, screen advertising is deeply involved in the complex orchestration of (im)mobility and the synchronization of different kinds of intermittent movements within the dispositif of train platforms.

\section{Conclusion}

This chapter has suggested an approach to screen advertising that takes the movement of moving image advertising and its temporal sequence as a starting point to study screen advertising in relation to other moving images as well as to moving bodies and objects. The spotlight on three prevailing media dispositifs in which screen advertising has been involved - postwar cinema, network-era television, and contemporary suburban train platforms - and on-screen advertising's interaction in the inter-relational dynamics between movements of images, bodies, and objects within these dispositifs has drawn attention to the temporal dimensions of the spatial media arrangements that we call dispositifs. It has also shown how screen advertising is interwoven with the rhythms of these dispositifs, and how it both structures and is structured by these rhythms.

The examination of screen advertising from the point of view of movements and mobilities has highlighted that the movements of images, objects, and bodies are defined by interruptions of movements. While screen advertising is often experienced as interruption, I argue that interruption is not a distinctive feature of advertising. Screen advertising may indeed draw attention to interruptions, but interruptions are the normal condition. This suggests that we think of movements of images, bodies, and objects as being intermittent and interlocked in complex dynamics between movement and stasis. What I hope to have shown is that screen advertising interacts in this dynamic of intermittent movements in a specific way - namely, in that it manages interruption and mediates transition: screen advertising mediates transitions between moving images in cinema and television programmes, between television channels, between the world of the diegesis and the 'real world' of the audience, and between different types and rhythms of movements. Screen advertising structures the interrelations of intermittent movements and works as an intermediary, stitching together different worlds and harmonizing different temporalities. In this sense, screen advertising is characterized by a permanent in-betweenness. It is in between worlds and in between movements 
and mobilities, at the threshold, itself a transient phenomenon that points to the future and bears promise for imminent change. Instead of interrupting the flow of movement, screen advertising, from this perspective, appears to connect intermittent flows with its 'visual mobility', to take up Williams's notion again, which helps create a permanent flow of different types of intermittent movements stitched together by screen advertising.

Thus, the temporalities of screen advertising are somewhat paradoxical: while commercials may interrupt a feature film, discontinue a television programme, or delay access to a YouTube video, for example, they also create continuity in keeping up visual mobility while moving forward in time. These paradoxical temporalities could be one explanation for the fact that, at some moments, we may experience screen advertising as a disturbance, while in other situations, we may be inclined to greet it as a welcome opportunity to while away time, to tune into the mood for a feature film in the cinema, or to get 'a few minutes smarter', as the Infoscreen Austria slogan has it. ${ }^{96}$

In all three dispositifs, screen advertising is significantly involved in an ongoing process of positioning viewers. In cinema, screen advertising helps immobilize bodily movements and turn inattention into captivation, thus co-producing, together with the technological arrangement, the subject position of the spectator. If Infoscreen gets people watching, as it claims to do, it certainly also positions viewers - and in doing so disciplines them in public spaces: travellers engaged in watching an Infoscreen will be less likely to play loud music, conduct themselves immorally, or litter. In that sense, screen advertising plays a key role not only in the sequential organization of moving images but also in the formal organization of spectatorship. As such, screen advertising is involved in the disciplining of audiences and can be considered an accomplice of governance.

\section{Bibliography}

Adey, Peter. 'If Mobility Is Everything then It Is Nothing: Towards a Relational Politics of (Im)mobilities.' Mobilities 1, no. 1 (2006): 75-94.

Albera François and Maria Tortajada. 'The Dispositive Does Not Exist.' In CineDispositives: Essays in Epistemology Across Media, edited by François Albera and Maria Tortajada, 21-44. Amsterdam: Amsterdam University Press, 2015.

96 In German, the slogan reads 'Und wieder ein paar Minuten klüger!' (And a few minutes smarter again), http://www.infoscreen.at/ (last accessed 21 March 2018). 
Altman, Rick. 'Television/Sound.' In Studies in Entertainment: Critical Approaches to Mass Culture, edited by Tania Modleski, 39-54. Bloomington: Indiana University Press, 1986.

Amsler, André. Wer dem Werbefilm verfällt, ist verloren für die Welt: Das Werk von Julius Pinschewer 1883-1961. Zurich: Chronos 1997.

'ARD-Richtlinien für Werbung, Sponsoring, Gewinnspiele und Produktionshilfe in der Fassung vom 12.03.2010.' 2, http://www.ard.de/download/553234/ ARD_Richtlinien_fuer_Werbung__Sponsoring__Gewinnspiele_und_Produktionshilfe_in_der_Fassung_vom_12_3_2010.pdf. Last accessed 6 April 2021.

'ARD-Rundfunkwerbung.' http://www.ard.de/home/intern/fakten/abc-der-ard/ Rundfunkwerbung/553184/index.html. Last accessed 6 April 2021.

Augé, Marc. Non-Places: An Introduction to Supermodernity, translated by John Howe. London: Verso: 2009 [1992].

Aumont, Jacques. L'Image. Paris: Nathan, 1990.

Baudry, Jean-Louis. 'Effets idéologiques produits par l'appareil de base.' Cinéthique no. $6 / 7$ (1970): 1-8.

Baudry, Jean-Louis. 'Le dispositive. Approches métapsychologiques de l'impression de réalité.' Communications 23 (1975): 56-72.

Birdsall, Carolyn, and Anthony Enns. 'Editorial: Rethinking Theories of Television Sound.' Journal of Sonic Studies 3, no. 1 (October 2012), https://hdl.handle. net/11245/1.377378. Last accessed 6 April 2021.

Bissell, David. 'Animating Suspension: Waiting for Mobilites.' Mobilities 2, no. 2 (July 2007): 277-298.

Bochsler, Regula, and Pascal Derungs, eds. Und führe uns in Versuchung: 1ooJahre Schweizer Werbefilm. Zurich: Museum für Gestaltung, 1998.

Boddy, William. 'Advertising Form, Technological Change and Screen Practices in the USA.' In Films That Sell: Moving Pictures and Advertising, edited by Bo Florin, Nico de Klerk, and Patrick Vonderau, 163-172. London and New York: Palgrave, 2016.

Budd, Mike, Steve Craig, and Clay Steinman. 'Fantasy Island: Marketplace of Desire.' In Mass Communication Review Yearbook, vol. 5, edited by Michael Gurevitch and Mark Levy, 291-301. Beverly Hills: Sage, 1985.

Butler, Jeremy G. Television: Critical Methods and Applications, $4^{\text {th }}$ ed. New York and London: Routledge, 2012.

Caldwell, John T. Televisuality: Style, Crisis, and Authority in American Television. New Brunswick: Rutgers University Press, 1995.

Chion, Michel. Audio-Vision: Sound on Screen, edited and translated by Claudia Gorbman. New York: Columbia University Press, 1994.

de Klerk, Nico. 'The Moment of Screening: What Non-Fiction Films Can Do.' In Triumph der Bilder: Kultur- und Dokumentarfilme vor 1945 im internationalen 
Vergleich, edited by Peter Zimmermann and Kay Hoffmann, 291-301. Konstanz: UVK, 2003.

Doane, Mary Ann. 'Information, Crisis, Catastrophe.' In Logics of Television, edited by Patricia Mellencamp, 222-239. Bloomington: Indiana University Press, 1990.

Ellis, John. 'Broadcast TV as Sound and Image.' In Film Theory and Criticism: Introductory Readings, edited by Gerald Mast, Marshall Cohen, and Leo Braudy, 385-394. New York: Oxford University Press, 1999.

Ellis, John. Visible Fictions: Cinema, Television, Video. London: Routledge, 1992.

'Fact Sheets on the European Union: Audiovisual and Media Policy.' http://www. europarl.europa.eu/atyourservice/en/displayFtu.html?ftuId=FTU_3.6.2.html. Last accessed 6 April 2021.

Feuer, Jane. 'Narrative Form in American Network Television.' In High Theory / Low Culture, edited by Colin MacCabe, 101-104. Manchester: Manchester University Press, 1986.

Fischer, Ludwig. 'Vorwort.' In Programm und Programmatik: Kultur-und medienwissenschaftliche Analysen, edited by Ludwig Fischer, 11-15. Konstanz: UVK, 2005.

Fiske, John. Television Culture. London and New York: Routledge, 1987.

Flitterman, Sandy. 'The Real Soap Operas: Tv Commercials.' In Regarding Television: Critical Approaches - An Anthology, edited by E. Ann Kaplan, 84-96. Los Angeles: American Film Institute and University Publications of America, 1983.

Forster, Ralf. Ufa und Nordmark: Zwei Firmengeschichten und der deutsche Werbefilm 1919-1945. Trier: Wissenschaftlicher Verlag Trier, 2005.

Foucault, Michel. Power/Knowledge: Selected Interviews and Other Writings 1972-1977, edited by Colin Gordon. New York: Pantheon Books, 1980.

Haller, Andrea, and Martin Loiperdinger. 'Stimulating the Audience: Early Cinema's Short Film Programme Format 1906 to 1912.' In Early Cinema Today: The Art of Programming and Live Performance, edited by Martin Loiperdinger, 7-21. New Barnet and Herts: John Libbey, 2011.

Hammond, Nick. 'Why Digital Out-of-Home Advertising Is not Really Digital (Yet).' 9 October 2017, https://www.econsultancy.com/blog/69491-why-digital-out-ofhome-advertising-is-not-really-digital-yet. Last accessed 6 April 2021.

Hannam, Kevin, Mimi Sheller, and John Urry. 'Editorial: Mobilities, Immobilities and Moorings.' Mobilities 1, no. 1 (March 2006): 1-22.

Hickethier, Knut. Film- und Fernsehanalyse, $3^{\text {rd }}$ revised ed. Stuttgart and Weimar: Metzler, 2001.

Hofer, André. 'Schon 20 Jahre TV-Werbung!' In TV Transit Express: AG für das Werbefernsehen. Bern, January 1985, n.p.

Huhtamo, Erkki. 'Messages on the Wall: An Archaeology of Public Media Displays.' In Urban Screen Reader, edited by Scott McQuire, Meredith Martin, and Sabine Niederer, 15-28. Amsterdam: Institute of Network Cultures, 2009. 
'Impressum.' http://www.infoscreen.at/infoscreen/impressum/. Last accessed 21 March 2018.

'Infoscreen Austria.' http://www.infoscreen.at/. Last accessed 21 March 2018.

Kackman, Michael et al., eds. Flow Tv: Television in the Age of Media Convergence. New York and London: Routledge, 2011.

Kessler, Frank. 'Notes on Dispositif.' Unpublished working paper, 2002.

Kreimeier, Klaus, Antje Ehmann, and Jeanpaul Goergen, eds. Geschichte des dokumentarischen Films in Deutschland, vol. 2: Weimarer Republik 1918-1933. Stuttgart: Reclam, 2005.

Loiperdinger, Martin. 'Julius Pinschewer - Pionier, Klassiker und Avantgardist des Werbefilms.' In Julius Pinschewer. Klassiker des Werbefilms, DVD Booklet 3-12. Berlin: absolut Medien, 2010.

Lotz, Amanda D. The Television Will Be Revolutionized. New York: New York University Press, 2007.

McCarthy, Anna. Ambient Television: Visual Culture and Public Space. Durham, NC and London: Duke University Press, 2001.

'Mediaplaner.' http://www.infoscreen.at/werben/mediaplaner/. Last accessed 21 March 2018.

Meyers, Cynthia B. 'The Best Thing on TV: 196os us Television Commercials.' In Films That Sell: Moving Pictures and Advertising, edited by Bo Florin, Nico de Klerk, and Patrick Vonderau, 173-193. London and New York: Palgrave, 2016.

Modleski, Tania. 'The Rhythms of Reception: Daytime Television and Women's Work.' In Regarding Television: Critical Approaches - An Anthology, edited by E. Ann Kaplan, 67-75. Los Angeles: American Film Institute and University Publications of America, 1983.

Moran, Joe. 'November in Berlin: The End of the Everyday.' History WorkshopJournal 57, no. 1 (Spring 2004): 216-234.

Oswald, Kathleen, and Jeremy Packer. 'Flow and Mobile Media: Broadcast Fixity to Digital Fluidity.' In Communication Matters: Materialist Approaches to Media, Mobility and Networks, edited by Jeremy Packer and Stephen B. Crofts Wiley, 276-287. London and New York: Routledge, 2012.

Outdoor Advertising Association of America (OAAA), 'History of ooH.' https://oaaa. org/AboutOOH/OOHBasics/HistoryofOOH.aspx. Last accessed 6 April 2021.

Outdoor Advertising Association of America (OAAA), 'OOH Value Proposition.' https://oaaa.org/AboutOOH/OOHBasics/OOHValueProposition.aspx. Last accessed 6 April 2021.

Overpeck, Deron. 'Subversion, Desperation, and Captivity: Pre-film Advertising in American Film Exhibition Since 1977.' Film History 22, no. 2 (2010): 219-234. Reichert, Ramón, ed. Kulturfilm im 'Dritten Reich.' Vienna: Synema, 2006. 
Schwartz, Barry. Queuing and Waiting: Studies in the Organization of Access and Delay. Chicago: University of Chicago Press, 1975.

Schweizer, Harold. 'On Waiting.' University of Toronto Quarterly, no. 3 (2005): 777-792.

Schweizerischer Reklame Verband, ed. Die Grundlagen der Filmwerbung: Eine Wegleitung für Auftraggeber. Zurich, [1949].

Sheller, Mimi, and John Urry, eds. Mobile Technologies of the City. London and New York: Routledge, 2006.

Sheller, Mimi, and John Urry. 'The New Mobilities Paradigm.' Environment and Planning A 38 (2006): 207-226.

Sjöholm, Carina. Gå på bio. Rum för drömmar i folkhemmets Sverige. Stockholm and Stehag: Brutus Östlings Bokförlag Symposion, 2003.

Straw, Will. 'Pulling Apart the Apparatus.' Recherches sémiotiques 31, no. 1-2-3 (2011), https://www.erudit.org/fr/revues/rssi/2011-v31-n1-2-3-rssio1601/1027441ar/. Last accessed 6 April 2021.

Ströer Media Data. 'Campaign Media Digital: Infoscreen.' (January 2017). Last accessed 21 March 2018; no longer available online. For Ströer Media Data 2021 on Infoscreen and DOOH, see https://www.stroeer.de/fileadmin/regional/ wt_downloads/9395.pdf?Mediadaten\%2oInfoscreen\%202021.pdf

Ströer Media Data. 'Profil-Auf einen Blick.' https://www.stroeer.com/unternehmen/ profil/auf-einen-blick.html. Last accessed 6 April 2021.

Urry, John. Sociology Beyond Societies: Mobilities for the Twenty-First Century. London: Routledge, 2000.

Waller, Gregory A. 'International Harvester, Business Screen and the History of Advertising Film.' In Films That Sell: Moving Pictures and Advertising, edited by Bo Florin, Nico de Klerk, and Patrick Vonderau, 40-53. London and New York: Palgrave, 2016.

Williams, Raymond. Television: Technology and Cultural Form. London and New York: Routledge, 2003 [1974].

'Willkommen bei Infoscreen, Ihrem Premium-Partner für Video in der Öffentlichkeit.' https://www.infoscreen.de/en/plan-calculate/media-locations/. Last accessed 21 March 2018.

Vonderau, Patrick. 'Introduction: On Advertising's Relation to Moving Images.' In Films That Sell: Moving Pictures and Advertising, edited by Bo Florin, Nico de Klerk, and Patrick Vonderau, 1-18. London and New York: Palgrave, 2016.

Vonderau, Patrick. 'Kim Novak and Morgan Stairways: Thinking about the Theory and History of the Tie-in.' In Films That Sell: Moving Pictures and Advertising, edited by Bo Florin, Nico de Klerk, and Patrick Vonderau, 209-220. London and New York: Palgrave, 2016. 
Vouilloux, Bernard. 'Du dispositif.' In Discours, image, dispositif, edited by Philippe Ortel. Paris: L'Harmattan, 2008.

Zimmermann, Peter, and Kay Hofmann, eds. Geschichte des dokumentarischen Films in Deutschland, vol. 3: 'Drittes Reich'1933-1945. Stuttgart: Reclam, 2005.

Zimmermann, Yvonne. 'Advertising and Film: A Topological Approach.' In Films That Sell: Moving Pictures and Advertising, edited by Bo Florin, Nico de Klerk, and Patrick Vonderau, 21-39. London and New York: Palgrave, 2016.

Zimmermann, Yvonne, ed. Schaufenster Schweiz: Dokumentarische Gebrauchsfilme 1896-1964. Zurich: Limmat, 2011. 